\title{
HUBUNGAN PENGETAHUAN PEKERJA DENGAN PERILAKU MENCEGAH PENULARAN COVID-19 DI PT. ARGATAMA MULTI AGUNG KECAMATAN CITEUREUP KABUPATEN BOGOR TAHUN 2021
}

\author{
Rita Sukmawati ${ }^{1}$, Rubi Ginanjar ${ }^{2}$, Ratih Fatimah ${ }^{3}$ \\ ${ }^{1}$ Peminatan Kesehatan dan Keselamatan Kerja, Program Studi Kesehatan Masyarakat, Fakultas Ilmu Kesehatan \\ Universitas Ibn Khaldun Bogor. Email : sukmawatirita875@gmail.com \\ 2,3 Program Studi Kesehatan Masyarakat, Fakultas Ilmu Kesehatan Universitas Ibn Khaldun Bogor \\ Email : ${ }^{1}$ rubiginanjar@gmail.com, ${ }^{2}$ ratihfatimah308@gmail.com
}

\begin{abstract}
Abstrak
Ditemukannya kasus positif COVID-19 pada klaster perkantoran dan industri/perusahaan harus diwaspadai peningkatannya karena berpotensi memberikan dampak secara luas, untuk itu perlu penerapan protokol kesehatan dengan baik agar mencegah timbulnya kasus COVID19 pada klaster industri/perusahaan. Tujuan dalam penelitian ini adalah mengetahui hubungan pengetahuan pekerja dengan perilaku mencegah penularan COVID-19 menggunakan metode penelitian kuantitatif dengan jumlah sampel sebanyak 55 responden menggunakan teknik accidental sampling. Data yang telah dikumpulkan selanjutnya diolah dan dianalisis dengan analisis data univariat dan bivariat. Hasil penelitian ini menunjukan bahwa tidak ada hubungan secara statistik antara umur pekerja dengan perilaku mencegah penularan COVID19 dengan $p$-value $=0,257$. Terdapat hubungan yang signifikan secara statistik untuk variabel pengetahuan $(p$-value $=0,003)$, sikap $(p$-value $=0,005)$, dan variabel ketersediaan sarana prasarana $(p$-value $=0,011)$ dengan perilaku mencegah penularan COVID-19 di PT. Argatama Multi Agung. Kesimpulan dalam penelitian ini adalah tidak terdapat hubungan antara umur dengan perilaku mencegah COVID-19 dan terdapat hubungan antara pengetahuan, sikap, ketersediaan sarana prasarana dengan perilaku mencegah penularan COVID-19 di PT. Argatama Multi Agung.
\end{abstract}

Kata Kunci : COVID-19, Pengetahuan, Perilaku

\section{PENDAHULUAN}

Coronavirus Disease 2019 (COVID-19) merupakan penyakit menular yang disebabkan oleh Coronavirus jenis baru yang kemudian diberi nama SARS-CoV-2 (Severe Acute Respiratory Syndrome Coronavirus 2). Di Indonesia Kasus Covid-19 pertama dilaporkan pada tanggal 2 Maret 2020 dan didapati jumlah kasus yang meningkat sampai saat ini. Pada Provinsi Jawa Barat, kasus terkonfirmasi kasus COVID-19 terbesar di Kabupaten Bekasi berasal dari klaster industri. Saat ini sudah mencapai $62 \%$ dari total kasus, kasus terkonfirmasi positif itu tersebar di puluhan perusahaan.

Timbulnya kasus COVID-19 disebabkan karena adanya pekerja dengan status positif COVID-19 dan merupakan orang tanpa gejala (OTG) yang tetap bekerja dengan membawa virus tanpa menyadarinya. Masih ditemukannya perusahaan yang tidak disiplin menerapkan 
protokol kesehatan juga menjadi salah satu timbulnya kasus positif pada klaster pabrik/perusahaan tetapi sudah banyak juga yang memperketat penerapan protokol kesehatan. Namun demikian, karyawan atau buruh belum tentu disiplin menerapkan protokol kesehatan saat beraktivitas di luar rumah dan di luar pabrik (Satgas Penanganan Covid-19, 2020).

Perilaku mencegah penularan COVID-19 berupa penerapan protokol kesehatan harus diterapkan, adapun faktor yang mempengaruhi perilaku menurut Lawrence Green yaitu umur, pendidikan, sikap, sarana prasarana, tradisi, peraturan, kepercayaan dan pengetahuan. Pengetahuan merupakan salah satu faktor predisposisi yang mempermudah terjadinya perilaku seseorang (Notoatmodjo 2011). Tujuan dalam penelitian ini untuk mengetahui hubungan pengetahuan pekerja dengan perilaku mencegah penularan COVID-19 di PT. Argatama Multi Agung Kecamatan Citeureup Bogor Jawa Barat.

Menurut Skiner (1938) dalam Notoatmodjo (2010) merumuskan bahwa perilaku merupakan respons atau reaksi seseorang terhadap stimulus atau rangsangan dari luar. Teori Lawrence Green dalam Natoatmodjo (2013) ada 3 faktor utama yang mempengaruhi perilaku seseorang yaitu, faktor predisposisi, faktor pemungkin, faktor penguat. Dalam pencegahan penularan COVID-19 diperlukan perilaku yang baik agar tidak tertular COVID-19.

Pencegahan dan Pengendalian COVID-19 di Lingkungan Kerja Perkantoran dan Industri Saat Kembali Bekerja Pasca Pembatasan Sosial Berskala Besar (PSBB) sudah tertuang dalam Keputusan Menteri Kesehatan Republik Indonesia Tentang Panduan Pencegahan dan Pengendalian COVID-19 di Tempat Kerja Perkantoran dan Industri Dalam Mendukung Keberlangsungan Usaha Pada Situasi Pandemi.

\section{METODE PENELITIAN}

Metode yang digunakan dalam penelitian ini merupakan metode penelitian kuantitatif dengan pendekatan observasional analitik. Jenis penelitian yang digunakan pada penelitian ini adalah cross sectional, penelitian ini dimaksudkan untuk mengetahui hubungan pengetahuan pekerja dengan perilaku mencegah penularan COVID-19 di PT. Argatama Multi Agung Kecamatan Citeureup Bogor Jawa Barat.

Jumlah populasi pada penelitian ini sebanyak 105 orang dibagian produksi, dengan jumlah sampel sebanyak 55 responden menggunakan teknik accidental sampling, yaitu suatu metode penentuan sampel dengan mengambil responden yang kebetulan ada atau tersedia di suatu tempat sesuai dengan konteks penelitian (Notoatmodjo, 2010).

Penelitian ini dilaksanakan pada bulan Agustus tahun 2021 dengan melakukan pengumpulan data menggunakan kuesioner dan observasi yang selanjutnya dibagikan kepada pekerja bagian produksi sebanyak 55 orang sesuai kriteria inklusi yang sudah ditentukan. Data yang telah dikumpulkan selanjutnya dianalisis menggunakan analisis univariat dan bivariat menggunakan uji statistic Chi-Square, yang bertujuan untuk menjelaskan hipotesis hubungan/pengaruh variabel independen dengan variabel dependen. 


\section{HASIL DAN PEMBAHASAN}

Berdasarkan penelitian yang dilakukan pada pekerja bagian produksi di PT. Argatama Multi Agung didapatkan sampel sebanyak 55 orang dengan distribusi frekuensi pengukuran sebagai berikut:

\section{A. Analisis Univariat}

Tabel 1. Distribusi Frekuensi Responden Berdasarkan Umur, Pengetahuan, Sikap, Sarana Prasarana, dan Perilaku Mencegah Penularan COVID-19 di PT. Argatama Multi Agung

\begin{tabular}{lcc} 
Kecamatan Citeureup Kabupaten Bogor Tahun 2021 \\
\hline Variabel & Frekuensi & Persentase (\%) \\
\hline Umur & & \\
$\leq 25$ Tahun & 32 & 58,2 \\
$>25$ Tahun & 23 & 41,8 \\
Total & 50 & 100 \\
\hline Pengetahuan & & \\
Cukup & 6 & 10,9 \\
Baik & 49 & 89,1 \\
Total & 55 & 100 \\
\hline Sikap & & \\
Negatif & 11 & 20,0 \\
Positif & 44 & 80,0 \\
Total & 55 & 100 \\
\hline Sarana Prasarana & & \\
Kurang & 8 & 14,5 \\
Baik\&Sangat Baik & 47 & 85,5 \\
Total & 55 & 100 \\
\hline Perilaku & & \\
Kurang & 8 & 14,5 \\
Baik & 47 & 85,5 \\
Total & 55 & 100 \\
\hline
\end{tabular}

Berdasarkan Tabel 1. diketahui bahwa pekerja yang menjadi responden didominasi oleh pekerja berusia $\leq 25$ Tahun sebanyak 32 orang (58,2\%), mayoritas responden memiliki pengetahuan baik tentang COVID-19 sebanyak 49 orang $(89,1 \%)$, responden yang memiliki sikap positif mengenai COVID-19 sebanyak 44 orang (80\%), responden dengan ketersediaan sarana prasarana kategori baik dan sangat baik sebanyak 47 orang (85,5\%), dan mayoritas responden memiliki perilaku baik mengenai pencegahan COVID-19 sebanyak 47 orang $(85,5 \%)$. 


\section{B. Analisis Bivariat}

Tabel 2. Hubungan Umur, Pengetahuan, Sikap, Sarana Prasarana dengan Perilaku Mencegah Penularan COVID-19 di PT. Argatama Multi Agung Kecamatan Citeureup Kabupaten Bogor Tahun 2021

\begin{tabular}{|c|c|c|c|c|c|c|c|c|}
\hline \multirow{3}{*}{ Variabel } & \multicolumn{4}{|c|}{ Perilaku Mencegah COVID-19 } & \multicolumn{2}{|c|}{ Total } & \multirow[t]{3}{*}{$P$-Value } & \multirow{3}{*}{$\begin{array}{l}\text { OR } \\
(95 \% \mathrm{CI})\end{array}$} \\
\hline & \multicolumn{2}{|c|}{ Kurang } & \multicolumn{2}{|c|}{ Baik } & & & & \\
\hline & $\mathrm{N}$ & $\%$ & $\mathrm{~N}$ & $\%$ & $\mathrm{~N}$ & $\%$ & & \\
\hline \multicolumn{9}{|l|}{ Umur } \\
\hline$\leq 25$ tahun & 3 & $9,4 \%$ & 29 & $90,6 \%$ & 32 & 100 & & \\
\hline$>25$ tahun & 5 & $21,7 \%$ & 18 & $78,3 \%$ & 23 & 100 & 0,257 & - \\
\hline Total & 8 & $14,5 \%$ & 47 & $85,5 \%$ & 55 & 100 & & \\
\hline \multicolumn{9}{|l|}{ Pengetahuan } \\
\hline Cukup & 4 & $66,7 \%$ & 2 & $33,3 \%$ & 6 & 100 & 0,003 & 22.5 \\
\hline Baik & 4 & $8,2 \%$ & 45 & $91,8 \%$ & 49 & 100 & & (3.102- \\
\hline Total & 8 & $14,5 \%$ & 47 & $85,5 \%$ & 55 & 100 & & 163.226) \\
\hline \multicolumn{9}{|l|}{ Sikap } \\
\hline Negatif & 5 & $45,5 \%$ & 6 & $54,5 \%$ & 11 & 100 & 0,005 & 11.4 \\
\hline Positif & 3 & $6,8 \%$ & 41 & $93,2 \%$ & 44 & 100 & & $\begin{array}{l}(2.148- \\
60.388)\end{array}$ \\
\hline Total & 8 & $14,5 \%$ & 47 & $85,5 \%$ & 55 & 100 & & \\
\hline \multicolumn{9}{|l|}{ Sarana } \\
\hline \multicolumn{9}{|l|}{ Prasarana } \\
\hline Kurang & 4 & $50 \%$ & 4 & $50 \%$ & 8 & 100 & 0,011 & 10.8 \\
\hline $\begin{array}{l}\text { Baik\&Sangat } \\
\text { Baik }\end{array}$ & 4 & $8,5 \%$ & 43 & $91,5 \%$ & 47 & 100 & & $\begin{array}{l}(1.918- \\
60.224)\end{array}$ \\
\hline Total & 8 & $14,5 \%$ & 47 & $85,5 \%$ & 55 & 100 & & \\
\hline
\end{tabular}

Berdasarkan tabel 2. dari hasil uji statistik diketahui bahwa tidak ada hubungan secara statistik antara umur dengan perilaku mencegah COVID-19 dengan $p$-value $=0,257$. Terdapat hubungan signifikan secara statistik antara pengetahuan pekerja dengan perilaku mencegah COVID-19 dengan $p$-value $=0,003$ dan diperoleh nilai OR sebesar 22.5 (95\% CI : 3.102 163.226). Terdapat hubungan signifikan secara statistik antara sikap pekerja dengan perilaku mencegah COVID-19 dengan $p$-value $=0,005$ dan diperoleh nilai OR sebesar 11.4 (95\% CI : 2.148-60.388). Terdapat hubungan signifikan secara statistik antara ketersediaan sarana prasarana pencegahan COVID-19 dengan perilaku pekerja dalam mencegah COVID-19 dengan $p$-value $=0,011$ dan diperoleh nilai OR sebesar 10.8 (95\% CI :1.918-60.224).

\section{PEMBAHASAN}

\section{Hubungan Umur dengan Perilaku Mencegah Penularan COVID-19}

Berdasarkan variabel umur pekerja, didapati hasil bahwa tidak ada hubungan secara statistik antara umur pekerja dengan perilaku mencegah COVID-19 di PT. Argatama Multi Agung Citeurep, dengan hasil uji Chi square menggunakan Fisher Exact Test diperoleh nilai $p$ value $=0,257$ nilai $p>a(0,05)$. 
Hasil penelitian ini sejalan dengan yang dilakukan Sari, dkk (2020) menyatakan bahwa tidak terdapat hubungan antara umur dengan perilaku pencegahan COVID-19 ( $p$-value= 0,306). Hasil penelitian ini sejalan dengan yang dilakukan Prihati, dkk (2020) dengan hasil uji statistik diperoleh $p$-value $=0.14$ yang berarti $>\alpha$, maka dapat disimpulkan bahwa usia responden tidak memiliki hubungan yang signifikan terhadap perilaku dalam pencegahan COVID-19

Dari hasil penelitian didapati bahwa baik pekerja yang berusia $\leq 25$ tahun dan $>25$ tahun di PT. Argatama Multi Agung Citeureup dapat berperilaku baik dalam mencegah penularan COVID-19. Hal ini didasari karena COVID-19 merupakan hal baru dan pengetahuan yang didapatkan tentang COVID-19 sama-sama diketahui ketika adanya kemunculan COVID-19 dan pencegahan COVID-19 harus dilakukan oleh semua kalangan usia baik muda maupun tua karena pekerja juga merasa pencegahan COVID-19 di tempat kerja harus diterapkan mengingat pekerja bagian produksi harus tetap bekerja di masa pandemi. Pada penelitian ini usia $\leq 25$ tahun lebih mendominasi perilaku baik dalam pencegahan penularan COVID-19, hal ini dikarenakan adanya proporsi yang tidak rata antara usia $\leq 25$ tahun dengan usia $>25$ tahun, dalam distribusi responden penelitian ini terlihat lebih banyak usia $\leq 25$ tahun $(58,2 \%)$ yang berpartisipasi dalam penelitian ini.

\section{Hubungan Pengetahuan dengan Perilaku Mencegah Penularan COVID-19}

Berdasarkan variabel pengetehuan pekerja, dari hasil uji statistik diperoleh nilai $p$-value $=0,003$ oleh karena nilai $p<$ a $(0,05)$, maka dapat disimpulkan bahwa terdapat hubungan signifikan secara statistik antara pengetahuan pekerja dengan perilaku mencegah COVID-19 di PT. Argatama Multi Agung Citeureup, yang berarti bahwa Ho ditolak. Dari hasil uji statistik diperoleh nilai OR sebesar 22.5 (95\% CI : 3.102-163.226) yang artinya pekerja dengan tingkat pengetahuan kategori baik memiliki peluang 22.5 kali lebih besar untuk berperilaku baik dalam mencegah COVID-19 dibandingkan pekerja dengan tingkat pengetahuan kategori cukup.

Sejalan dengan penelitian Yanti, dkk (2021) yang berjudul "Community Knowledge Attitudes And Behavior Towards Sosial Distancing Policy As Prevention Transmission of COVID-19 In Indonesia", dengan didapati nilai $p$-value $=0,001$ dan nilai a = 0,05 yang artinya terdapat hubungan yang signifikan antara pengetahuan dengan perilaku pencegahan COVID19. Pengetahuan merupakan salah satu faktor predisposisi yang mempermudah terjadinya perilaku seseorang (Notoatmodjo 2011). Pengetahuan memiliki kaitan yang erat dengan keputusan yang akan diambilnya, karena dengan pengetahuan seseorang memiliki landasan untuk menentukan pilihan. Selain itu tingkat pengetahuan juga didukung dengan tingkat pendidikan, tingkat pendidikan pekerja yang tinggi akan semakin mudah untuk mendapatkan akses informasi tentang suatu permasalahan (Yanti B dkk, 2020).

Salah satu hal yang mempengaruhi perilaku adalah pengetahuan. Menurut Notoatmodjo (2011), sebagian pengetahuan manusia diperoleh melalui mata dan telinga. Pengetahuan mengenai pencegahan COVID-19 di tempat kerja yang diperoleh pekerja baik dari penyuluhan di tempat kerja maupun dari hasil membaca atau penglihatan menumbuhkan persepsi yang baik pada pekerja tentang perilaku pencegahan penularan penyakit. Oleh karena itu pekerja dengan pengetahuan yang baik tentang COVID-19 akan berperilaku yang baik pula dalam mencegah penularan COVID-19 di PT. Argatama Multi Agung Citeureup. 


\section{Hubungan Sikap dengan Perilaku Mencegah Penularan COVID-19}

Berdasarkan variabel sikap, dari hasil uji statistik diperoleh nilai $p$-value $=0,005$ oleh karena nilai $p<a(0,05)$, maka dapat disimpulkan bahwa terdapat hubungan signifikan secara statistik antara sikap pekerja dengan perilaku mencegah COVID-19 di PT. Argatama Multi Agung Citeureup, yang berarti bahwa Ho ditolak. Dari hasil uji statistik diperoleh nilai OR sebesar 11.4 (95\% CI : 2.148-60.388) yang artinya pekerja dengan sikap positif memiliki peluang 11.4 kali lebih besar untuk berperilaku baik dalam mencegah COVID-19 dibandingkan pekerja dengan sikap negatif.

Penelitian ini sejalan dengan penelitian Wulandari (2021) dengan judul "Hubungan Pengetahuan dan Sikap dengan Perilaku Pencegahan COVID-19 Pada Penderita Tuberkolosis di Rumah Sakit Paru" yang menyatakan bahwa terdapat hubungan antara sikap dengan perilaku pencegahan COVID-19 pada penderita tuberkolosis dengan nila $p$-value $=0,000$. Masyarakat dalam hal ini adalah pekerja bagian produksi di PT. Argatama Multi Agung Citeureup harus memiliki sikap positif dalam menghadapi pandemi COVID-19 sehingga dapat melakukan pencegahan dan dapat mengurangi risiko tertular COVID-19 di tempat kerja dan di tempat umum lainnya, mengingat saat pandemi COVID-19 pekerja industri masih harus bekerja di tempat kerja karena kegiatan pekerjaan yang tidak bisa diselesaikan jika dilakukan di rumah atau biasa disebut Work Form Home (WFH).

Sebuah sikap positif mengenai COVID-19 akan meningkatkan niat untuk berpeilaku yang baik. Sebaliknya, sikap negatif mengenai COVID-19 akan mengurangi niat untuk berperilaku baik. Menurut teori Lawrence Green (1980) perilaku ditentukan oleh 3 faktor dimana salah satu faktonya yaitu faktor predisposisi yaitu faktor-faktor yang dapat mempermudah terjadinya perilaku pada diri seseorang, adalah pengetahuan dan sikap terhadap apa yang akan dilakukan. Dalam perilaku mencegah COVID-19 di PT. Argatama Multi Agung akan dipermudah apabila pekerja mengetahui apa manfaat melakukan pencegahan COVID-19, dan mengetahui bagaimana cara mencegahnya.

\section{Hubungan Sarana Prasarana dengan Perilaku Mencegah Penularan COVID-19}

Berdasarkan variabel sarana dan prasarana, dari hasil uji statistik diperoleh nilai $p$-value $=0,011$ oleh karena nilai $p<$ a $(0,05)$, maka dapat disimpulkan bahwa terdapat hubungan signifikan secara statistik antara ketersediaan sarana prasarana pencegahan COVID-19 dengan perilaku pekerja dalam mencegah COVID-19 di PT. Argatama Multi Agung Citeureup, yang berarti bahwa Ho ditolak. Dari hasil uji statistik diperoleh nilai OR sebesar 10.8 (95\% CI :1.91860.224) yang artinya pekerja dengan ketersediaan sarana prasarana pencegahan COVID-19 yang sangat baik memiliki peluang 10.8 kali lebih besar untuk berperilaku baik dalam mencegah COVID-19 dibandingkan pekerja dengan ketersediaan sarana prasarana pencegahan COVID-19 yang baik .

Penelitian ini sejalan dengan yang dilakukan Salilah (2020) yang menyatakan ada hubungan ketersediaan sarana dan prasarana dengan perilaku pencegahan COVID-19 ( $p$ value $=0,006: p<0,05)$. Tersedianya sarana prasarana dapat memungkinkan seseorang untuk melakukan perilaku pencegahan COVID-19. Hal ini sejalan dengan teori L. Green yang menyatakan bahwa salah satu faktor yang mempengaruhi perilaku seseorang adalah faktor 
pemungkin yaitu ketersediaan sarana dan prasarana. Dalam hal ini adalah sarana dan prasarana yang menunjang perilaku pencegahan Penularan COVID-19 di PT. Argatama Multi Agung Citeureup sudah tersedia dengan sangat baik namun ada disatu area dimana letak sarana cuci tangan cukup jauh dari area pekerja bagian produksi dan ventilasi serta sirkulasi udara yang tidak berfungsi dengan baik. Dari hasil observasi dan wawancara yang dilakukan juga tidak tersedia penanda jaga jarak pada area padat pekerja dan APD berupa masker tidak disediakan oleh perusahaan karena para pekerja sudah memakai masker dan membawa masker dari rumah.

\section{KESIMPULAN}

Berdasarkan hasil penelitian dapat disimpulkan bahwa tidak ada hubungan antara umur dengan perilaku mencegah penularan COVID-19, dan terdapat hubungan antara pengetahuan pekerja, sikap, ketersediaan sarana dan prasarana dengan perilaku mencegah penularan COVID-19 di PT. Argatama Multi Agung Kecamatan Citeureup Kabupaten Bogor Tahun 2021.

\section{DAFTAR PUSTAKA}

Arikunto, S. (2010). Prosedur Penelitian: Suatu Pendekatan Praktik. Jakarta: Rineka Cipta.

Atun, Farihatun \& Zulazmi Mamdy. (2016). Faktor Faktor Yang Berhubungan Dengan Perilaku Pencegahan Penyakit Malaria Pada Masyarakat di Desa Karyamukti Kecamatan Cibalong Kabupaten Garut Provinsi Jawa Barat. Jurnal Kesehatan Bakti Tunas Husada. Vol. 15, No. 1.

Avianty, I., Luthfi, F., Suharto,, ...Ginanjar, R., Nasution, A.S. (2021). Nutritional status, dust exposure and risk factors for acute respiratory infections for workers in industrial estates. Indian Journal of Forensic Medicine and Toxicologythis link is disabled, 2021, 15(1), pp. $1156-1160$

Afrilyani, R.,Supriyanto \& Ginanjar, R. 2019. Gambaran Kepatuhan Petugas Laboratorium Terhadap Penggunaan Alat Pelindung Diri di Rumah Sakit Salak Bogor Tahun 2017. Jurnal Mahasiswa Kesehatan Masyarakat, 2 (4): 306-312

A Nasution, A Maulana, D Kurniawan. (2019). BERSAMA MEMAJUKAN DESA. Abdi Dosen: Jurnal Pengabdian Pada Masyarakat 3 (2), 99-104

Asri Masitha Arsyati, Vindi Krisna Chandra, 2020. Assement Kesiapan Kader Posyandu dalam Pelatihan Penggunaan Media Online. HEARTY Jurnal Kesehatan Masyarakat Vol.8 No.1, 2020 Agustus-February, hlm. 27-32 ISSN. 2338-7475 E-ISSN. 2620-7869

Badan Pusat Statistik RI. (2020). Survei Perilaku Masyarakat di Masa Pandemi COVID-19. BPS RI.

DD Lestari, SK Parinduri, R Fatimah. (2020). HUBUNGAN WAKTU TUNGGU PELAYANA RAWAT JALAN TERHADAP KEPUASAN PASIEN DI POLIKLINIK SPESIALIS PENYAKIT DALAM RSUD KOTA BOGOR TAHUN 2018-2019. PROMOTOR 3 (3), 231-240

F Azka, TN Prastia, FD Pertiwi. (2020). GAMBARAN PENGETAHUAN IBU TENTANG TEKNIK MENYUSUI DI KELURAHAN TEGALGUNDIL KOTA BOGOR. PROMOTOR 3 (3), 241-250

FD Pertiwi, SN Nurdiana. (2019). HUBUNGAN SIKAP DENGAN PENGALAMAN (BULLYING) PADA SISWA SMKN 2 KOTA BOGOR. HEARTY: Jurnal Kesehatan Masyarakat 7 (1) 
Fitrianingtyas, Pertiwi, dan Rachmania, W. Faktor-Faktor yang Berhubungan dengan Kejadian Kurang Energi Kronis (KEK) pada Ibu Hamil di Puskesmas Warung Jambu Kota Bogor. HEARTY Jurnal Kesehatan Masyarakat. 2018;6(2):1-8.

Ginanjar, R., Fathimah, A., \& Aulia, R. 2018. Analisis Risiko Ergonomi Terhadap Keluhan Musculoskeletal Disorders (MSDs) Pada Pekerja Konveksi Di Kelurahan Kebon Pedes Kota Bogor Tahun 2018. Jurnal Mahasiswa Kesehatan Masyarakat, 1(2).

Hastono, Sutanto P. (2016). Analisis Data Pada Bidang Kesehatan. Jakarta: PT Raja Grafindo Persada.

Istiqomah, dkk. (2017). Faktor-Faktor Yang Berhubungan Dengan Upaya Pencegahan Demam Berdarah Dangue Pada Ibu Rumah Tangga Di Kelurahan Kramas Kota Semarang. Jurnal Kesehatan Masyarakat. Volume. 5, No. 1.

International Labour Organization. (2020). Dalam Menghadapi Pandemi: Memasikan Keselamatan dan Kesehatan di Tempat Kerja.

Kementrian Kesehatan RI. (2019). Modul Bahan Ajar Cetak Kebidanan Kesehatan Masyarakat.

Pusat pendidikan sumber daya manusia kesehatan badan pengembangan dan pemberdayaan sumber daya manusia kesehatan.

Keputusan Menteri Kesehatan Republik Indonesia Nomor HK. 01. 07/ MENKES/328/2020

Tentang Panduan Pencegahan dan Pengendalian Corona Virus Disease 2019 (COVID-19)

di Tempat Kerja Perkantoran dan Industri Dalam Mendukung Keberlangsungan Usaha Pada Situasi Pandemi.

Pratama S., Asnifatima A., Ginanjar R., 2019, Faktor-Faktor Yang Berhubungan Terhadap Postur

Kerja Dengan Keluhan Nyeri Punggung Bawah Pada Pengemudi Bus Pusaka Di Terminal Baranangsiang Kota Bogor Tahun 2018, Promotor Jurnal Mahasiswa Kesehatan Masyarakat Vol.2, No.4

Puspitasari, S. Supriyanto. Ginanjar, R. (2019). Faktor-Faktor yang Berhubungan dengan Kecelakaan Kerja Tertusuk Jarum Suntik atau Benda Tajam Lainnya Pada Perawat di RSUD Leuwiliang Kabupaten Bogor Tahun 2018. Promotor Jurnal Mahasiswa Kesehatan Masyarakat, 2(2), 163-171.

Pertiwi, F. D., Hariansyah, M., \& Prasetya, E. P. (2019). FAKTOR RISIKO STUNTING PADA BALITA DIKELURAHAN MULYAHARJA TAHUN 2019. PROMOTOR, 2(5). https://doi.org/10.32832/pro.v2i5.2531

Raya, M. R., Asnifatimah, A. and Ginanjar,R. 2018. Faktor-Faktor yang Mempengaruhi Keluhan Gangguan Pendengaran Pada Supir Bus POPusaka Di Terminal BaranangsiangKota Bogor Tahun 2018.JurnalPromotor Vol 2 No 2.

R Fatimah, SW Utomo. (2020). STRES OKSIDATIF PADA PEKERJA YANG TERPAJAN BENZENA MELALUI PENGUKURAN PLASMA MALONDIALDEHID (MDA)(STUDI KASUS PADA PEKERJA BENGKEL SANDAL/SEPATU DI DESA SUKAJAYA, KECAMATAN ... . HEARTY: Jurnal Kesehatan Masyarakat 8 (1)

R Fatimah. (2021). PENYULUHAN PEMBERIAN MPASI TEPAT DAN ADEKUAT DI KELURAHAN GENTENG, KECAMATAN CIPAKU, BOGOR TAHUN 2019. PROMOTOR 4 (1), 8-11

S Nurdiana, FD Pertiwi, E Dwimawati. (2021). FAKTOR-FAKTOR YANG BERHUBUNGAN DENGAN PENGALAMAN BULLYING DI SMK NEGERI 2 BOGOR PROVINSI JAWA BARAT TAHUN 2018. PROMOTOR 3 (6), 605-613 
Woldometers. (2020). Data kasus COVID-19 di Dunia dan Asia. https://www.worldometers.info

Yanti, Ni Putu, dkk. (2020). Gambaran Pengetahuan Masyarakat Tentang COVID-19 dan Perilaku Mayarakat di Masa Pandemi COVID-19. Jurnal Keperawatan Jiwa. Vol. 8, No. 3.

Yanti, B. dkk. (2020). Community Knowledge Attitudes And Behavior Towards Sosial Distancing Policy As Prevention Transmission of COVID-19 In Indonesia. JAKI (Jurnal Administrasi Kesehatan Indonesia). Vol. 8.

World Health Organization. (2020). Definisi Coronavirus Disease (COVID-19). https://www.who.int

Wulandari, Dwi. dkk. (2021). Hubungan Tingkat Pengetahuan dengan Perilaku Pencegahan COVID-19 di Desa Lebak Peniangan Lampung. ARTERI: Jurnal Ilmu Kesehatan. Vol. 2. No. 2 . 